\title{
Modern Marketing Research Techniques and Policymaking in Wyoming's State Budgeting: An Abstract
}

\author{
Mark Peterson and Robert W. Godby
}

\begin{abstract}
Like the energy-based economies of Alaska and North Dakota, Wyoming's economy entered a recession in 2016 due to low energy prices. This thrust the state into a budget crisis that remains unresolved. In May 2016, researchers deployed state-of-the-art marketing research methods to shed light on how Wyoming citizens feel about budget options for the state legislature in the current times of economic recession in the state. These researchers used a discrete-choice modeling approach to better understand relative preferences among budgeting options facing the state legislature. Their findings suggest that Wyomingites generally align with actions of the state legislature taken in February 2016 with the exception of the legislature's decision to not accept federal funding for expanding Medicaid to all Wyoming residents. The study's success suggests that other levels of government (such as cities, counties, public utility commissions, as well as the federal government) can gain collective intelligence by accessing citizen preferences in a timely manner for their own policymaking efforts.
\end{abstract}

M. Peterson $(\bowtie) \cdot$ R. W. Godby

University of Wyoming, Laramie, WY, USA

e-mail: markpete@uwyo.edu; rgodby@uwyo.edu 